\title{
Effects of Cypermethrin on the Hematological Parameters, Biochemical Components of Blood and Histopathological Changes in Different Organs of Chirruh Snow Trout (Schizothorax esocinus)
}

\author{
Naveed Akhtar ${ }^{1 *}$, Muhammad Fiaz Khan ${ }^{1 *}$, Sadia Tabassum ${ }^{1}$, \\ Munawar Saleem Ahmad ${ }^{2}$ and Khan Dil Badshah ${ }^{3}$ \\ ${ }^{1}$ Department of Zoology, Hazara University, Mansehra, Pakistan \\ ${ }^{2}$ Department of Zoology, University of Swabi, Pakistan \\ ${ }^{3}$ Department of Chemistry, Government Postgraduate College, Haripur, Pakistan
}

Article Information
Received 10 April 2019
Revised 04 June 2019
Accepted 20 June 2019
Available online 25 March 2021
Authors' Contribution
MFK and ST designed and supervised
the study. NA conducted the study.
MSA and KDB helped in sample
collection and analysis.
Key words
Cypermethrin, Schizothorax esocinus,
Genotoxicity

\begin{abstract}
A B S T R A C T
The current study describes effect of different concentrations of cypermethrin on hematological parameters, biochemical components of blood, histopathological changes in different organs and DNA damage in Chirruh snow trout Schizothorax esocinus. WBCs, RBCs, hemoglobin, hematocrit, MCV, MCH, MCHC and platelets were significantly decreased in all treated groups compared to control. Monocytes showed significant increase in all experimental groups. Lymphocytes counts significantly decreased in all treated groups compared to control groups. Neutrophils count increased significantly in all treated groups. Among electrolytes, sodium and potassium levels were increased, whereas, calcium and phosphorous levels decreased in all treated groups. From amongst biochemical components of blood triglycerides, cholesterol, urea and protein level decreased, whereas in the glucose level increased in all treated groups. In histopathology, dose dependent lesion and alterations in gills, liver, brain, kidney, intestine and muscles related with oxidative stress damage was observed. Genotoxicity increased with increase in time and concentration of cypermethrin. Cypermethrin is therefore extremly harmful to aquatic life.
\end{abstract}

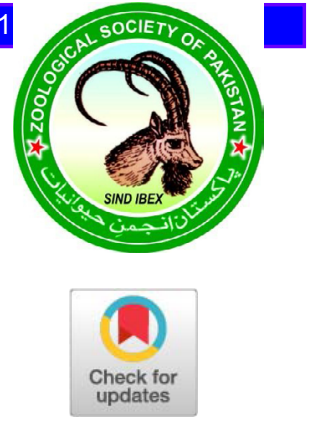

\section{INTRODUCTION}

I nsecticides are chemicals practiced for averting and monitoring pests, containing trajectories of humanoid or animal infections. They have been practiced for regulating undesirable floras or faunas triggering injury to the manufacture, handling, storing, advertising of foodstuff, agronomic possessions, timber goods, animal materials, which might be given to animals for controlling pests or additional insects attached to their bodies (WHO, 2002).

Pyrethroid and organophosphates are among the widely used pesticides. Pyrethroids are imitated type of pyrethrins (Soderlund et al., 2002). Pyrethroid have two varieties which differ in biochemical organization; in variety I allethrin, tetramethrin, resmethrin, bioremethrin, and permethrin are present, whereas variety II have cypermethrin, cyfluthrin, cyphenothrin and deltamethrin

\footnotetext{
Corresponding author: akhtarzoologist@gmail.com; fiazkhanhu333@gmail.com 0030-9923/2021/0003-0943 \$ 9.00/0

Copyright 2021 Zoological Society of Pakistan
}

(Wang et al., 2006).

Cypermethrin (CYP), a synthetic pyrethroid, is one of the most effective insecticide used in forestry, agriculture, buildings and farmyards (Casida et al., 1983; Khan et al., 2006; Ullah et al., 2015). Commercially CYP is being used against cotton and soybean pests (Carriquiriborde et al., 2007). The insecticides which are sprayed in the fields ultimately land into water bodies, posing serious threat to aquatic life particularly fish. In addition, some aqua culturists also use CYP as a chemotherapeutic agent to eradicate different copepod infestations (Medina et al., 2002; Athanassopoulou et al., 2009; Nafees et al., 2009). Consequently, CYP due to its diffusion and surface runoff into natural water reservoirs, seemed as a main hazard to the aquatic fauna including fishes (John and Prakash, 2003). Fish due to its habitat is directly exposed to environmental noxiousness including harmful insecticides disclosure which effects its profitable worth and rearing ability (Georgieva et al., 2014; Firat et al., 2011).

Blood parameters are intensively used as biological indicators of fish health (Lermen et al., 2004). Therefore, evaluation of blood parameters is good for detecting the 
health status (Dorucu and Girgin, 2001; Ranzani-Paiva et al., 2005; Pimpao et al., 2007). Fish is highly at health risk to pyrethroid exposure (Moraes et al., 2013) and fish toxicity increases with increase in value of toxin per liter (Guner, 2009). Pesticides are accumulated in tissues like liver and muscle that result in dysfunction of organ and ultimately result is loss of fish (Srivastava and Kaushik, 2001). Many enzymes in fish are important for normal biological role and disruption in in the activity of enzymes act as primary indicator of contaminant toxicity (Jensen et al., 1991). The aim of this study was to assess the toxic effects of sublethal concentrations of cypermethrin on hematology, biochemistry, histopathology and DNA damage in freshwater fish Schizothorax esocinus.

\section{MATERIALS AND METHODS}

This research was conducted in Department of Zoology, Post Graduate College Haripur. All the guidelines were followed provided by the ethical committee of Post Graduate College Haripur.

\section{Test species and laboratory care}

Fish specimens of chirruh snow trout (Schizothorax esocinus $\mathrm{n}=25$ ) were collected from river Swat and were transported to laboratory in a small glass aquarium having aerated oxygen. Fish were acclimatized for one week before starting the experiment. Five specimens were kept in each aquarium. Persistent oxygen was bubbled via air pumps in aquaria.

\section{Experimental design}

Cypermethrin ([S, R]-N- $\alpha$-cyno-3-phenoxybenzyl(IR, IS, cis, trans)-2, 2-dimethyl-3, (2, 2-dichlorovinyl, cyclopropane carboxylate), used in this study was purchased from a local market. Four different concentrations i.e., $1.00 \mathrm{ppb}, 2.00 \mathrm{ppb}, 3.00 \mathrm{ppb}$ and $4.00 \mathrm{ppb}$ of CYP were formulated from a commercial devising carrying $32 \%$ active ingredients. Five fishes were stocked in each aquarium of $100 \mathrm{~L}$ water capacity which were filled up to $60 \mathrm{~L}$. Each aquarium was provided with different concentration of CYP and were labeled as, $\mathrm{C} 0, \mathrm{C} 1, \mathrm{C} 2, \mathrm{C} 3$ and $\mathrm{C} 4$. C0 was kept as control group, $\mathrm{C} 1$ had $1.00 \mathrm{ppb}, \mathrm{C} 2$ had $2.00 \mathrm{ppb}, \mathrm{C} 3$ had $3.00 \mathrm{ppb}$ and $\mathrm{C} 4$ had $4.00 \mathrm{ppb}$ CYP. Fishes were exposed to CYP for $96 \mathrm{~h}$ to these concentrations. After $96 \mathrm{~h}$, fishes were anesthetized in clove oil. Blood was taken from caudal vein using $1 \mathrm{ml}$ disposable syringe for hematology, electrolytes, metabolites, enzymes and DNA damage study. Fish was sacrificed to take tissues of brain, gills, kidney, liver, intestine and muscles.

\section{Hematological parameters}

WBCs and RBCs were measured manually by following the protocol provided by Hrubec et al. (1996). Hemoglobin was assessed spectrophotometrically by cyanomethaemoglobin technique described by (Drabkin, 1964). MCV, MCH, MCHC, platelets, monocytes, lymphocytes and neutrophils $\left(10^{9} / \mathrm{L}\right)$ were estimated according to Jain (1986). Blood smears, were stained with Wright's Giemsa stain and used for the differential cell count as described by Hrubec et al. (1996).

\section{Biochemical parameters}

For biochemical analysis, the clotted blood samples were centrifuged to separate serum which was used for estimation of biochemical parameters using Chem Reader SBA-733 Plus (Semi-auto Chemistry analyzer, Advanced Japanese Technology). Biochemical parameters included in this study were; Electrolytes (Calcium, Potassium, Phosphorus and Sodium), Metabolites (Total Protein, Glucose, Creatinine, Urea, Cholesterol and Triglycerides) and Enzymes (Lactate Dehydrogenase (LDH) Alanine, Alkaline Phosphatase (ALP), Aspartate Aminotransferase (AST) and Aminotransferase (ALT)).

\section{Histopathology}

Gills, brain, liver, intestine, kidney and muscles tissues were dissected out of fish, fixed in $10 \%$ formalin followed by dehydration by passing through different grades of alcohol. The tissues were embedded in 4-5 $\mu \mathrm{m}$ thick sections were cut and stained hematoxylin and eosin.

\section{Comet assay}

The genotoxicity was executed by following the technique used by Singh et al. (1988). Blood samples were mixed in saline solution of $1000 \mu \mathrm{l}$. Using $10 \mathrm{uL}$ of saline solution slides were prepared and $(0.5 \%)$ of low melting agarose of $120 \mu \mathrm{l}$ at $37^{\circ} \mathrm{C}$. In lysis solution consisting ( $1 \mathrm{~mL}$ of Triton X-100, $10 \mathrm{~mL}$ of DMSO and $89 \mathrm{~mL}$ of lysing solution stock, $\mathrm{pH} 10.0$ - stock solution: $2.5 \mathrm{M}$ of $\mathrm{NaCl}, 100 \mathrm{mM}$ of EDTA100, $10 \mathrm{mM}$ to $1 \mathrm{~L}$ of Tris) slides were kept for 60 minutes in the refrigerator. Slides after 60 minutes, slides were kept in a horizontal electrophoresis system at $25 \mathrm{~V}, 300 \mathrm{~mA}$ for 20 minutes. For about 15 minutes slides were neutralized with $0.4 \mathrm{M}$ of Tris having $\mathrm{pH} 7.5$, and stable in ethanol for 10 minutes. Those cells in which no DNA damage occurred move consistently, whereas those cells having DNA damage, they showed fragments of dissimilar masses, and minor cells move quicker in electrophoresis, so make the tail of a comet. 
Table I. Effect of different concentration of cypermethrin on hematological parameters of Schizothorax esocinus.

\begin{tabular}{llllll}
\hline Hematology & Control group & $\mathbf{1 ~ p p m}$ & $\mathbf{2 ~ p p m}$ & $\mathbf{3} \mathbf{p p m}$ & $\mathbf{4} \mathbf{p p m}$ \\
\hline WBC $\left(10^{9} / \mathrm{L}\right)$ & $2.88 \pm 0.017$ & $2.72 \pm 0.95$ & $2.60 \pm 0.84$ & $2.42 \pm 1.02$ & $2.28 \pm 0.52$ \\
RBC $\left(\mathrm{X} 10^{12} / \mathrm{L}\right)$ & $3.7 \pm 0.47$ & $3.4 \pm 0.17$ & $3.2 \pm 0.10$ & $3.0 \pm 0.11$ & $2.9 \pm 0.10^{*}$ \\
Hemoglobin (g/dL) & $12.8 \pm 0.50$ & $09.86 \pm 0.13$ & $09.54 \pm 0.15^{*}$ & $09.34 \pm 0.15$ & $09.30 \pm 0.92^{*}$ \\
Hematocrit (\%) & $36.5 \pm 0.94$ & $35.10 \pm 0.13^{*}$ & $33.8 \pm 0.13^{*}$ & $28.2 \pm 0.09$ & $27.1 \pm 0.07^{*}$ \\
MCV (fL) & $97.1 \pm 10.5$ & $95.20 \pm 0.86^{*}$ & $92.80 \pm 1.28^{*}$ & $88.40 \pm 0.92^{*}$ & $86.20 \pm 0.58^{*}$ \\
MCH (Pg) & $36.2 \pm 0.89$ & $33.1 \pm 0.89^{*}$ & $30.80 \pm 1.03^{*}$ & $28.61 \pm 1.24^{*}$ & $26.20 \pm 0.80^{*}$ \\
MCHC (g/dL) & $31.6 \pm 2.8$ & $28.40 \pm 1.43^{*}$ & $26.40 \pm 1.43^{*}$ & $24.80 \pm 0.58^{*}$ & $21.62 \pm 0.13^{*}$ \\
Platelets (X10/L) & $3.8 \pm 0.05$ & $3.52 \pm 0.09$ & $3.26 \pm 0.02$ & $3.0 \pm 0.75$ & $2.80 \pm 0.02$ \\
Monocytes (X10/L) & $4.5 \pm 1.16$ & $4.60 \pm 1.24$ & $4.9 \pm 1.28$ & $5.2 \pm 0.33$ & $5.60 \pm 0.73$ \\
Lymphocytes (X10/L) & $66.8 \pm 1.5$ & $61.86 \pm 1.41$ & $60.1 \pm 1.38$ & $57.28 \pm 1.75$ & $54.60 \pm 1.83$ \\
Neutrophils (X10/L) & $25.4 \pm 1.74$ & $26.20 \pm 1.77$ & $29.6 \pm 1.06$ & $31.0 \pm 1.83$ & $34.4 \pm 1.73$ \\
\hline
\end{tabular}

Data is presented as Mean $\pm \mathrm{SD}(\mathrm{n}=5$ fish per treatment $)$. Mean with * show significant variance $(\mathrm{p}<0.05)$.
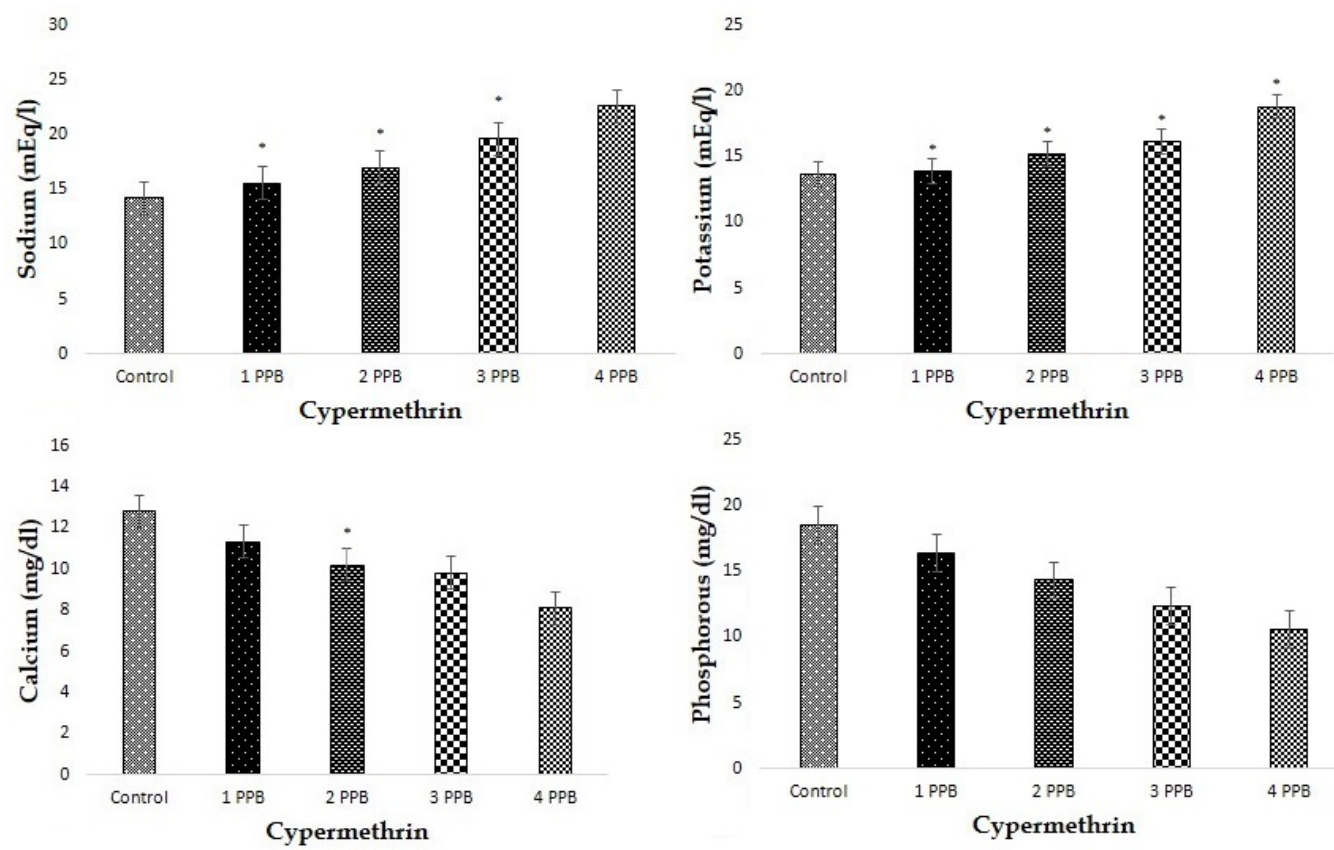

Fig. 1. Effect of different concentration of cypermethrin on electrolytes level of S. esocinus.

\section{Statistical analysis}

Data was analyzed using SPSS software (Version 24.0). Comparison was made among all of the four experimental groups using one-way ANOVA followed by LSD. Variables were stated as means and standard deviations. $\mathrm{p}<0.05$ was statistically significant.

\section{RESULTS}

\section{Hematological parameters}

Table I show the effect of CYP on blood parameters.
Decrease is observed was WBCs, RBCs, Hb, HCT, MCV, $\mathrm{MCH}, \mathrm{MCHC}$ and platelets levels of all treated groups. Monocytes showed increase in all treated groups. Lymphocytes showed decrease in number in all treated groups. Neutrophils counts showed increase in all groups.

Biochemical components of blood

Figure 1 shows effect of different concentration on level of electrolytes in the fish serum. Increase was observed in sodium level and potassium level in all treated groups, whereas calcium and phosphorous level showed 
decreased level in all treated groups.

\section{Metabolic components of blood}

Figure 2 shows effect of different concentration cypermethrin on triglycerides, cholesterol and urea which decreased in all treated groups. Creatinine showed no changes. Glucose level showed increase in all treated groups. Total protein level decreased in all treated groups.

\section{Liver enzymes}

Figure 3 shows increase in ALP, ALT, AST and LDH activities in all treated groups after cypermethrin administration.

\section{Histological observation}

Compared to control gills tissue show significant alterations and lesions including shortening of lamellae, erosion of gills arch, blood congestion, necrosis, lamellar curling, hypertrophy of epithelial cells, degenerative changes, shortening of secondary gills lamellae, degeneration of epithelial cells and lamellar destruction (Fig. 4). Brain exhibited pyknosis, degenerative changes, necrosis and blood congestion (Fig. 5). Intestine showed blood congestion, necrosis, destructive changes, ulceration of mucosa, loss of structural integrity, pyknosis, shrinkage of mucosa and necrosis of tip (Fig. 6). Kidney showed vacuolation, interstitial hemorrhage, hyperactivated MM, interstitial hemorrhage and multifocal granulomas (Fig. 7). Liver exhibited disappearance of hepatic cell wall, densely packed hepatocytes, bile pigment, necrosis, leukocyte infiltration and pyknosis (Fig. 8). Muscles showed muscles necrosis and fragmentation of sarcoplasm (Fig. 9).
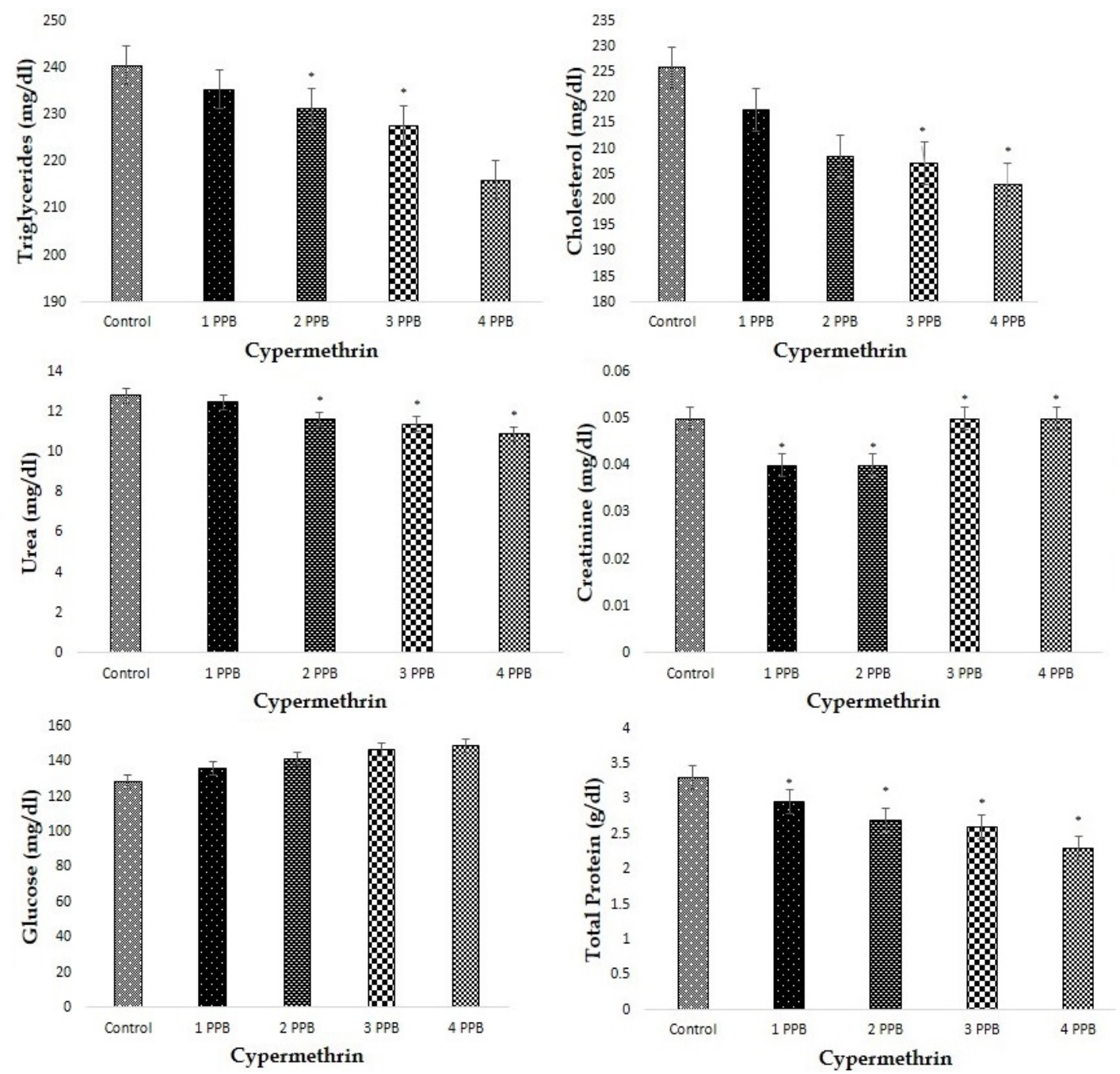
Fig. 2. Effect of different concentration of cypermethrin on various biochemical components of S. esocinus.
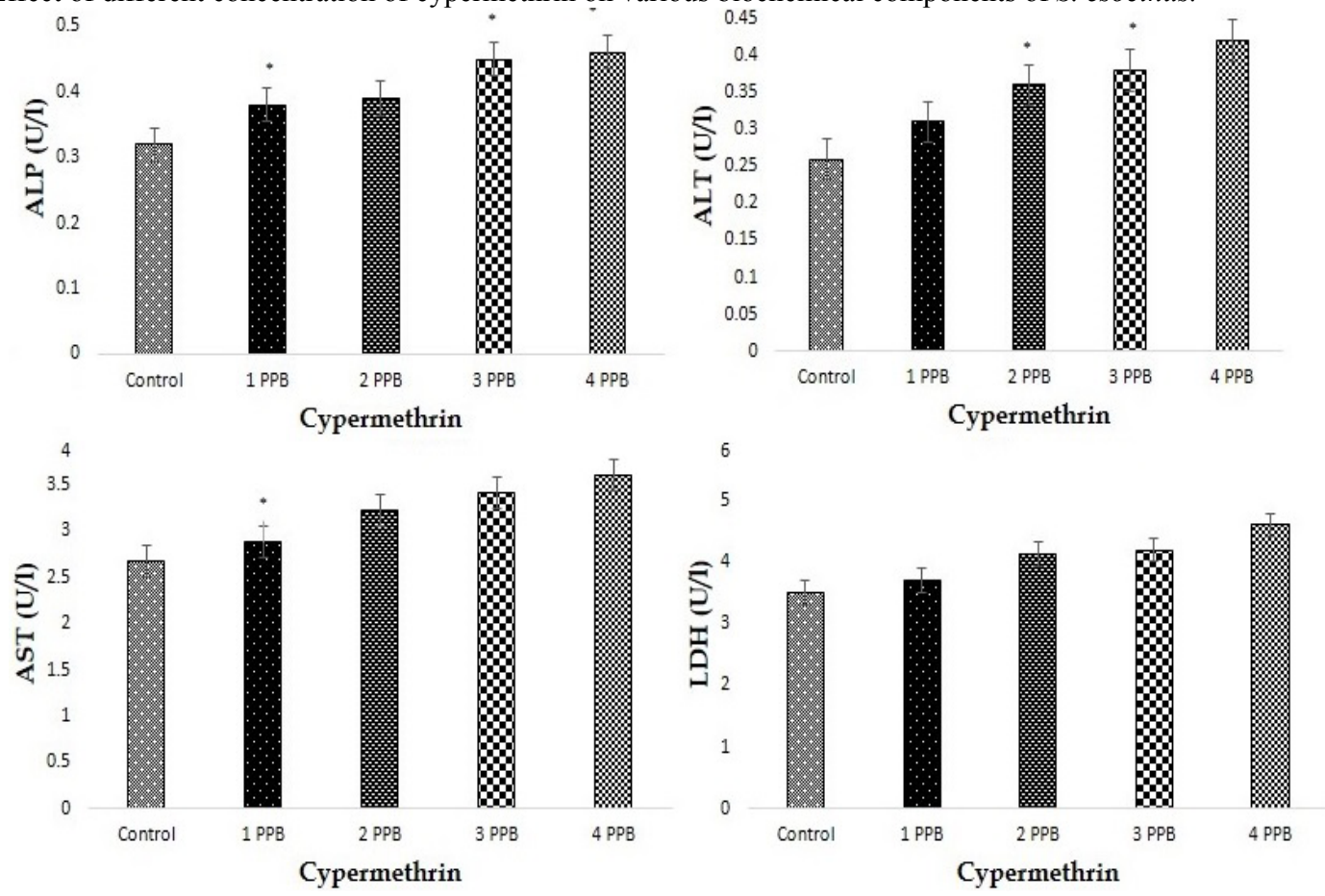

Fig. 3. Effect of different concentration of cypermethrin on liver function enzymes in blood serum.

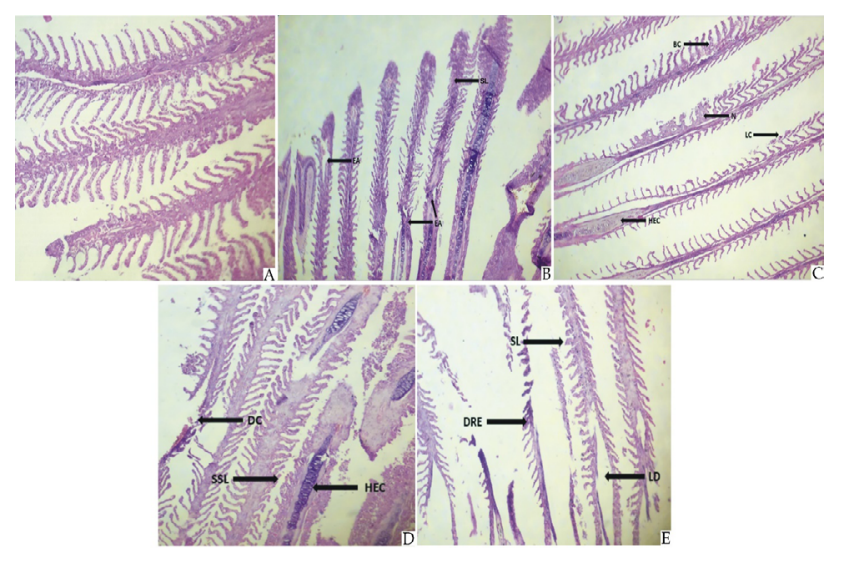

Fig. 4. Effect of different concentration of cypermethrin on Gills of Schizothorax esocinus. (A) Control showing no lesions no necrosis and have normal primary and secondary lamellae. (B) fishes exposed to 1 ppb showing (SL) Shortening of lamellae and (EA) Erosion of gills arch. (C) fishes exposed to $2 \mathrm{ppb}$ showing (BC) Blood congestion, (N) Necrosis, (LC) Lamellar curling and (HEC) Hypertrophy of epithelial cells. (D) fishes exposed to $3 \mathrm{ppb}$ showing (DC) Degenerative changes, (SSL) Shortening of secondary gills lamellae and (HEC) Hypertrophy of epithelial cells. (E) fishes exposed to $4 \mathrm{ppb}$ showing (SL) Shortening of lamellae, (DRE) Degeneration of epithelial

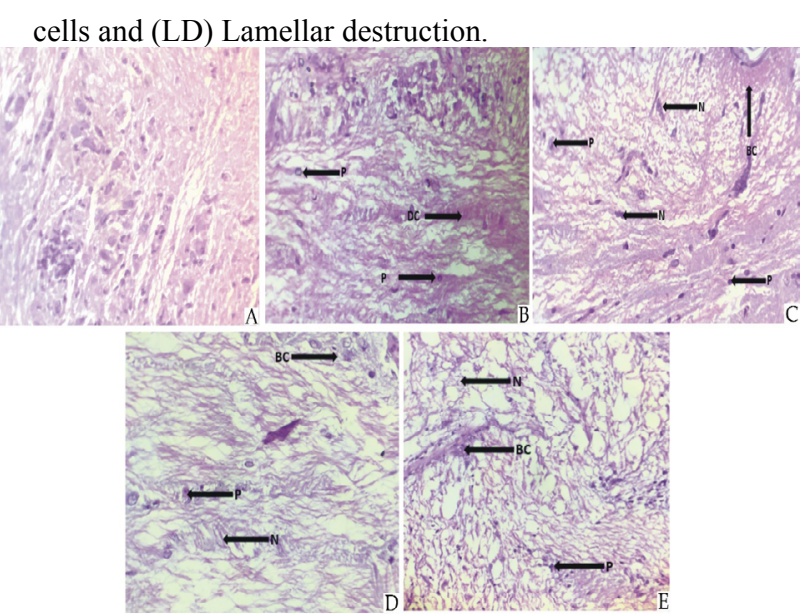

Fig. 5. Effect of different concentration of cypermethrin on various histological structure of Brian of Schizothorax esocinus. (A) Control showing normal fish brain having no discolouration, no lesions, no morphological changes and have normal hippocampus. (B) fish exposed to $1 \mathrm{ppb}$ showing (P) Pyknosis and (DC) Degenerative changes. (C) fish exposed to 2 ppb showing (P) Pyknosis, (N) Necrosis and (BC) Blood congestion. (D) fish exposed to $3 \mathrm{ppb}$ showing (BC) Blood congestion, $(\mathrm{N})$ Necrosis and $(\mathrm{P})$ Pyknosis. (E) fish exposed to $4 \mathrm{ppb}$ showing (BC) Blood 
congestion, (N) Necrosis and (P) Pyknosis.

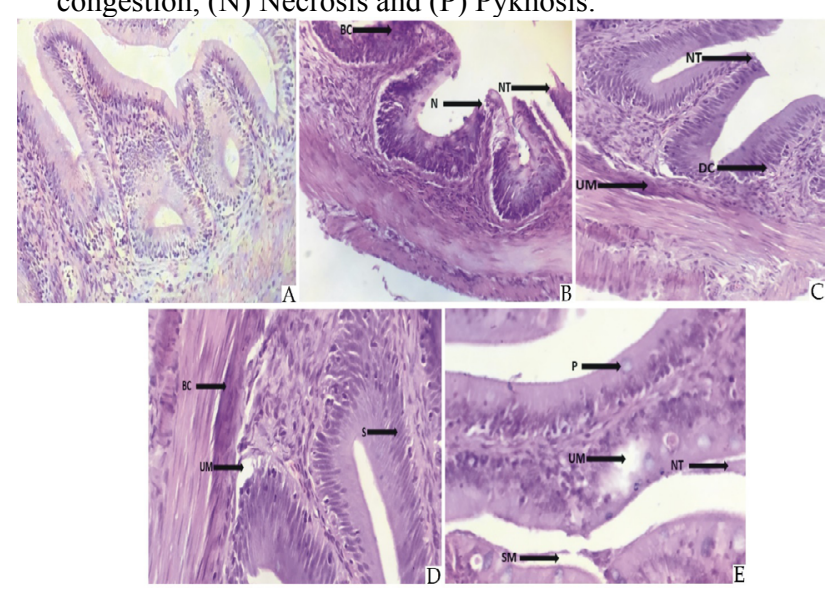

Fig. 6. Effect of different concentration of cypermethrin on various histological structure of intestine of Schizothorax esocinus. (A) Control showing normal structure of intestine, epithelium, serosa and sub mucosa. (B) fish exposed to 1 ppb showing (BC) Blood congestion, $(\mathrm{N})$ Necrosis and (NT) Necrosis of tip. (C) fish exposed to 2 ppb showing (NT) Necrosis of tip, (DC) Destructive changes and (UM) Ulceration of mucosa. (D) fish exposed to 3 ppb showing (BC) Blood congestion, (S) structural integrity loss and (UM) Ulceration of mucosa. (E) fish exposed to $4 \mathrm{ppb}$ showing (UM) Ulceration of mucosa, (P) Pyknosis, (NT) Necrosis of tip and (SM) Shrinkage of mucosa.

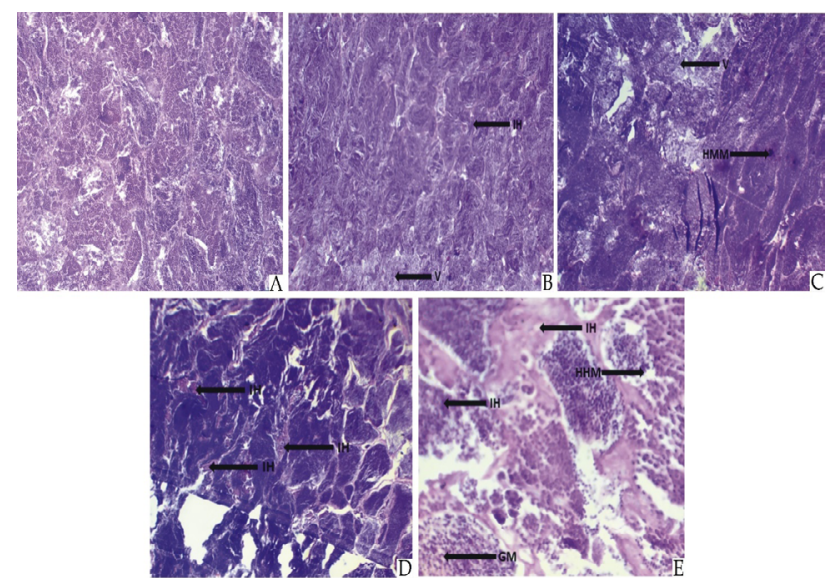

Fig. 7. Effect of different concentration of cypermethrin on various histological structure of Kidney of Schizothorax esocinus. (A) Control showing histology of kidney with normal glomerulus, tubules and interstitial tissues. (B) fish exposed to $1 \mathrm{ppm}$ showing (V) Vacuolation and (IH) Interstitial hemorrhage. (C) fish exposed to 2 ppm showing (HMM) Hyperactivated MM and (V) Vacuolation. (D) fish exposed to $3 \mathrm{ppm}$ showing (IH) Interstitial hemorrhage. (E) fish exposed to $4 \mathrm{ppm}$ showing (IH) Interstitial hemorrhage, (GM) Multifocal granulomas and (HMM)

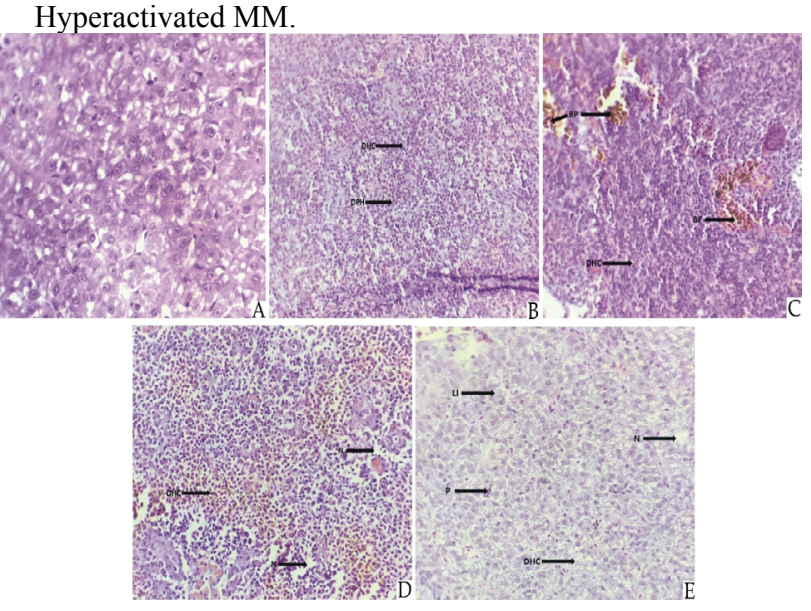

Fig. 8. Effect of different concentration of cypermethrin on various histological structure of Liver of Schizothorax esocinus. (A) Control showing normal hepatocytes, hepatopancrease and sinusoids. (B) fish exposed to $1 \mathrm{ppb}$ showing (DHC) Disappearance of hepatic cell wall and (DPH) Densly packed hepatocytes. (C) fish exposed to 2 ppb showing (BP) Bile pigment and (DHC) Disappearance of hepatic cell wall. (D) fish exposed to 3 ppb showing (DHC) Disappearance of hepatic cell wall and (N) Necrosis. (E) fish exposed to $4 \mathrm{ppb}$ showing (Li) Leukocyte infiltration, (DHC) Disappearance of hepatic cell wall, (P) Pyknosis and (N) Necrosis.

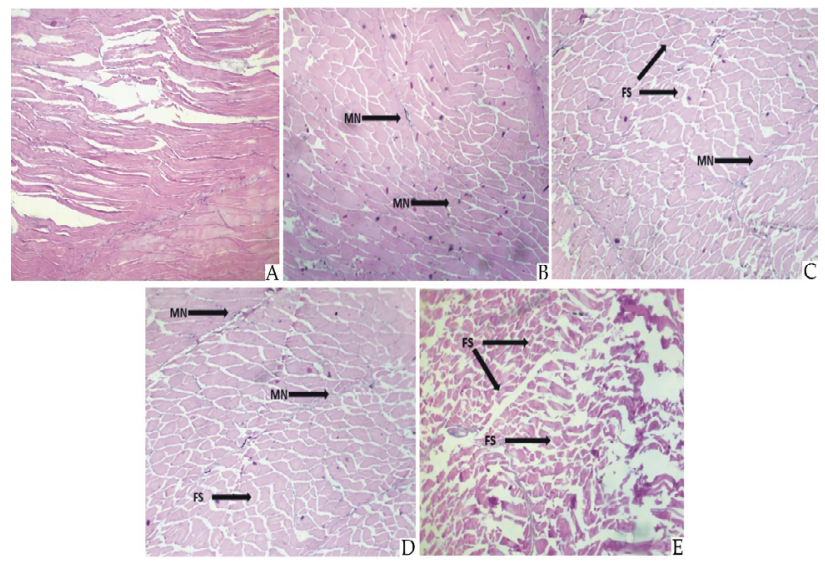

Fig. 9. Effect of different concentration of cypermethrin on various histological structure of smooth muscles of Schizothorax esocinus. (A) Control showing normal fish muscle having no necrosis and fragmentation. (B) fish exposed to $1 \mathrm{ppm}$ showing (MN) Muscles necrosis. (C) fish exposed to $2 \mathrm{ppm}$ showing (FS) Fragmentation of sarcoplasm and (MN) Muscles necrosis. (D) fish exposed to $3 \mathrm{ppm}$ showing (MN) Muscles necrosis and (FS) Fragmentation of sarcoplasm. (E) fish exposed to $4 \mathrm{ppm}$ showing (FS) Fragmentation of sarcoplasm. 


\section{Comet assay}

After the exposure of S. esocinus to CYP damage occurd in peripheral blood erythrocytes. Genotoxicity increased with increase in the concentration of CYP. CI has DNA damage of $0.001 \%$ which showed low DNA damage. $\mathrm{C} 2$ has DNA damage of $23.87 \%$ showing higher DNA damage. C3 has of DNA damage of $23.67 \%$ showing higher DNA damage. C4 has DNA damage of $63.62 \%$ showing higher DNA damage (Fig. 10).

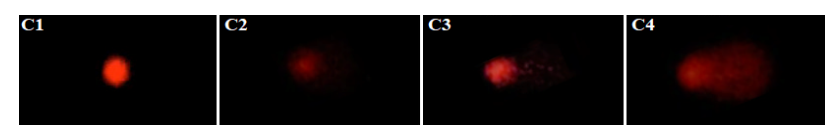

Fig. 10. Effect of different concentration of cypermethrin on the DNA damage in peripheral blood erythrocytes using comet assay in control and treated group of Schizothorax esocinus. C1, I ppb; C2, 2 ppb; C3, 3 ppb; C4, 4 ppb.

\section{DISCUSSION}

This study was assessed to estimate the toxic potential of cypermethrin, on chirruh snow trout S. esocinus. Blood characteristics of fish express major deviation, and various ecological and lethal toxins can persuade broad variations (Zahran et al., 2018). Reduction in blood parameters of exposed fishes to insecticides, designate low RBC count results because we of blood formation, ion-change irregularity and proliferation in WBCs damage in blood producing tissues (Jenkins et al., 2003; Seth et al., 2003). In present study reduction occurred in WBC value. Other studies show increase in WBC counts in fishes exposed to different concentrations of cypermethrin (Akinrotimi et al., 2012; Masud et al., 2013). In our study decrease is observed in RBCs, $\mathrm{Hb}, \mathrm{HCT}, \mathrm{MCV}, \mathrm{MCH}$ and $\mathrm{MCHC}$ exposed to different concentrations of CYP. Our findings are similar to previous studies conducted by (Masud et al., 2013; Velmurugan et al., 2016) in which they reported reduction of $\mathrm{RBC}$, hemoglobin, hematocrit, $\mathrm{MCV}, \mathrm{MCH}$ and $\mathrm{MCHC}$ level after exposure to different concentrations of CYP. In our study lymphocytes decreased whereas monocytes and neutrophils increased in all treated groups. Similar findings are reported by (Akinrotimi et al., 2012) in which they reported increase in neutrophils level. Montanha et al. (2014) reported no such changes in neutrophil, lymphocytes, monocyte.

Changes in biological parameters in due to ecological trauma is supported by different researchers in many species Channa punctatus (Topal et al., 2014), Labeo rohita (Kishor et al., 2014), Cirrhinus mrigala (Sreekala and Zutshi, 2012). In our study increase is observed in sodium level and potassium level, whereas decrease is observed in calcium and phosphorous level in all treated groups. Similar findings are reported by (Atamanalp et al., 2002) in which he reported decrease in calcium and phosphorous after exposure of fish to cypermethrin. In our study decrease is observed in triglycerides, cholesterol and urea in all treated groups. Similar findings are reported by (Orun et al., 2014) in which they reported decrease $(p<0.05)$ in the levels of triglycerides, whereas other researchers reported higher values of cholesterol, urea and triglycerides in fish exposed to different concentration of CYP (Bhanu and Deepak, 2015; Ojutiku et al., 2013). This variation may be due to change in species. In our study increase is observed in glucose level in all treated groups. Similar findings are reported by (Bhanu and Deepak, 2015 ) in which he reported increase in glucose level after exposure of C. carpio to CYP. In our study decrease is observed in total protein level in all treated groups. Similar results are reported by (Bhanu and Deepak, 2015) in which they reported decrease in proteins level of fish after exposure to CYP. In our study increase is observed in ALP, ALT, AST and LDH activity in all treated groups. Similar findings are reported by (Ojutiku et al., 2013) by reporting increase in Alanine aminotransferase (ALT) and Aspartate aminotransferase (AST) in fish after exposure to CYP (Ojutiku et al., 2013). Similarly, increase is reported in Aspartate aminotransferase (AST) in fish treated with concentrations of 1.5 and 2.5 of cypermethrin (Montanha et al., 2014). Similarly, increase in aspartate aminotransferase (AST), lactate dehydrogenase (LDH) is reported in fish after exposure to CYP (Velisek et al., 2006).

In fish, histology variation serves as powerful and precise tags in valuation of fish status after exposure to contaminants (Van der Oost et al., 2003). Gills are the first target of fishes on exposure to insecticides and are major index for water excellence (Qureshi et al., 2016). Gills besides absorbing oxygen is busy in other vital tasks like exchange of ions, acid base equilibrium and removal of hazardous substances from body, therefore environmental pollutants destroy such important tissues badly and enforce unwanted noteworthy problems on body of fish (Bantu et al., 2017). In our study gills exposed to different concentrations of cypermethrin show shortening of lamellae, erosion of gills arch, blood congestion, necrosis, lamellar curling, hypertrophy of epithelial cells, degenerative changes, shortening of secondary gills lamellae, degeneration of epithelial cells and lamellar destruction. Other researchers reported similar findings as (Khan et al., 2018) reported lamellar disorganization, disruption of cartilage, epithelial lifting, loss, fusion, 
curling and shortening of secondary gills lamellae, atrophy and blood congestion. Common carp exposed to different concentrations of atrazine show alteration in gills including severe lamellar teleangiectasis, dilated lamellar capillaries filled with erythrocytes, rupture of dilated lamellar capillary and pooling of the blood with formation of thrombi (Blahova et al., 2014). Gills of Nile thilapia treated with chlorpyrifos indicate, abnormality and merging of secondary lamellae, mild hyperplasia of epithelial cells, accumulation of mucus, severe epithelial hyperplasia, lamellar necrosis, degradation in respiratory epithelial cells and connective tissue cells (Zahran et al., 2018).

Intestine is a major organ of fish, having chief part in ingestion and adjustment of food. It might be used as tag organ in ecotoxicology due to its delicate nature to all type of lethal substances (Khan et al., 2018). In our study intestine exposed to different concentrations of cypermethrin show blood congestion, necrosis, destructive changes, ulceration of mucosa, loss of structural integrity, pyknosis, shrinkage of mucosa and necrosis of tip. Rohu (L. Rohita) exposed to different concentrations of cypermethrin show alterations in intestines including, cup cells construction in villi, shortening of villi, fusion of villi, necrosis, hemorrhages and pyknosis (Khan et al., 2018).

Kidney of fish have key work in homeostasis, erythropoieses and removal of injurious substances as it is main tissues which is damaged by toxins in water atmosphere (Thophon et al., 2003; Neelima et al., 2015). In our study kidney exposed to different concentrations of cypermethrin show vacuolation, interstitial hemorrhage, hyperactivated MM, interstitial hemorrhage and multifocal granulomas. Nile thalipia exposed to different concentrations of chlorpyrifos show lesions in kidney including, interstitial amassing of eosinophilic watery liquid, hyperactivated MM, interstitial fluid, adequate vacuolization of epithelial lining proximal and distal tubules, interstitial hemorrhage, extensive aggregation of MNCs, austere vacuolization of epithelial lining proximal and distal tubules as well as enlarged interstitial space (Zahran et al., 2018).

Liver is among the main organs in body due to its key function in metabolism of protein, carbohydrates and fats. Accumulation of insecticides and their byproducts in liver results in important histology modification and variation in liver (Sharma et al., 2012) In our study liver exposed to different concentrations of cypermethrin show disappearance of hepatic cell wall, densely packed hepatocytes, bile pigment, necrosis, leukocyte infiltration and pyknosis. Others researchers reported similar changes in liver of $L$. rohita treated with cypermethrin, like termination of cell membrane, blood congestion, congestion, pyknosis, necrosis, hyperplasia and vacuolations of hepatocytes (Khan et al., 2018). Common carp exposed to atrazine show lesions in live including vacuolar degeneration of hepatocytes (Blahova et al., 2014). Liver of Nile thilapia exposed to chlorpyrifos show sporadic region with peculiar cores, mobbed blood vessels with perivascular MNCs accumulation, vacuolization of pancreatic cells, reduction and necrosis of pancreatic cells and MNCs aggregation nearby hepatopancreas (Zahran et al., 2018).

In our study brain exposed to different concentrations of cypermethrin show pyknosis, degenerative changes, necrosis and blood congestion. Brain of cyprinus carpio treatd with 2, 4-D NA salt, glyphosate and paraquat present, swelling of pyramidal cells with binucleated nucli, austere necrosis of neuron of cerebrum showing damage of nissl substances, mild vacular variations with hollow spaces, tegmentum was completely disappeared and number of neuroglial cells decreased (Deivasigamani, 2015). Similarly, C. carpio exposed to phorate show, mild degenerative changes, mild structural damage, degenerative changes, structural degeneration and congestion of neural cells in brain (Lakshmaiah, 2017). Cyprinus carpio exposed to quinalphos show, mild degenerative changes in neural cells, structural damage, necrotic changes in neural cells and intracellular edema, increased necrotic condition of neural cells and cytoplasmic vacuolization observed, slight degenerative changes and vacuolization (Chamarthi et al., 2014).

In our study muscles exposed to different concentrations of cypermethrin show muscles necrosis and fragmentation of sarcoplasm. Muscles of Tilapia nilotica exposed to pendimethlain show, muscle necrosis with calcified muscles, muscle necrosis with fragmentation of sarcoplasm, muscle necrosis with calcified muscles and mononuclear cell infiltration (Abd-Algadir et al., 2011).

Mutilation in DNA is due to significance oxidative stress, xenobiotic metabolites or xenobiotic (Santos and Martinez, 2012). Neotropical fish Prochilodus lineatus treated with different concentrations of atrazine result in increased DNA destruction (Santos and Martinez, 2012). Cyprinus carpio treated with fipronil and buprofezin in combinations result in increased genotoxicity in whole blood DNA content (Bantu et al., 2017). Genotoxicity of C. carpio exposed to oxadiazon was conducted through comet assay, which result in significantly higher DNA damage $(21.3 \%, 22.9 \%$, and $28.4 \%$, respectively) (Zanjani et al., 2017). In our study $S$. esocinus exposed to different concentration of CYP cause damage in DNA of peripheral blood erythrocytes. Low DNA damage (0.001\%) was observed at $1 \mathrm{ppb}$ exposure whereas higher DNA damage $(63.62 \%)$ was observed at 4 ppb concentration. It is evident that genotoxicity increased with increase in the concentration of CYP. 


\section{CONCLUSION}

The present study reveals that cypermethrin is toxic to Schizothorax esocinus even at low concentration. Cypermethrin promote hematological, biochemical, histopathological alterations and genotoxicity in $S$. esocinus. It is harmful to aquatic life; therefore, its use should be minimized and alternative techniques should be adopted.

\section{ACKNOWLEDGMENT}

This study was supported by higher education commission of Pakistan (10108).

\section{Statement of conflict of interest}

The authors declare no conflict of interest.

\section{REFERENCES}

Abd-Algadir, M.I., Idris, O.F. and Elkhier, M.K.S., 2011. Effect of pendimethalin herbicide on fish (Tilapia nilotica) skeletal muscles, gills and its influence on human. World J. Life Sci. med. Res., 1: 5.

Akinrotimi, O.A., Gabriel, U.U. and Ariweriokuma, S.V., 2012. Haematotoxicity of cypermethrin to African catfish Clarias gariepinus under laboratory conditions. J. Environ. Enginee. Technol., 1: 20-25.

Atamanalp, M., Keles, M.S., Haliloglu, H.I. and Aras, M.S., 2002. The effects of cypermethrin (a synthetic pyrethroid) on some biochemical parameters $(\mathrm{Ca}, \mathrm{P}$, $\mathrm{Na}$ and TP) of rainbow trout (Oncorhynchus mykiss). Turk. J. Vet. Anim. Sci., 26: 1157-1160.

Athanassopoulou, F., Pappas, I. and Bitchava, K., 2009. An overview of the treatments for parasitic disease in Mediterranean aquaculture. Options Méditerr. Ser A., 86: 65-83.

Bantu, N., Kumari, N. and Vakita, R., 2017. Histological alteration in different tissues of Indian major carp, Labeo rohita (Hamilton) exposed to Profenofos $50 \%$ EC and Carbosulfan 25\% EC formulations. J. Biol. Today World, 6: 38-45. https://doi.org/10.15412/J. JBTW.01060301

Bhanu, A.P. and Deepak, M., 2015. Impact of cypermethrin on biochemical aspects of clinical importance in the blood of freshwater fish Cyprinus carpio. J. Ent. Zool. Stud., 3: 126-128.

Blahova, J., Modra, H., Sevcikova, M., Marsalek, P., Zelnickova, L., Skoric, M. and Svobodova, Z.,
2014. Evaluation of biochemical, haematological, and histopathological responses and recovery ability of common carp (Cyprinus carpio L.) after acute exposure to atrazine herbicide. BioMed. Res. Int., 8 : 1-7. https://doi.org/10.1155/2014/980948

Carriquiriborde, P., Díaz, J., Mugni, H., Bonetto, C. and Ronco, A.E., 2007. Impact of cypermethrin on stream fish populations under field-use in biotechsoybean production. Chemosphere, 68: 613-621. https://doi. org/10.1016/j.chemosphere.2007.02.051

Casida, J.E., Gammon, D.W., Glickman, A.H. and Lawrence, L.J., 1983. Mechanisms of selective action of pyrethroid insecticides. Annu. Rev. Pharmacol. Toxicol., 23: 413-438. https://doi. org/10.1146/annurev.pa.23.040183.002213

Chamarthi, R.R., Bangeppagari, M., Gooty, J.M., Mandala, S., Tirado, J.O. and Marigoudar, S.R., 2014. Histopathological alterations in the gill, liver and brain of Cyprinus carpio on exposure to quinalphos. Am. J. Life Sci., 2: 211-216. https://doi. org/10.11648/j.ajls.20140204.14

Deivasigamani, S., 2015. Effect of herbicides on fish and histological evaluation of common carp (Cyprinus carpio). Int. J. appl. Res., 1: 437-440.

Dorucu, M. and Girgin, A., 2001. The effect of cypermethrin on some hematological parameters of Cyprinus capio. Aquacult. Int., 9: 183-187. https:// doi.org/10.1023/A:1014297528028

Drabkin, D., 1964. Spectrophotometric studies; the crystallographic and optical properties of man $\mathrm{Hbs}$ in comparison with those of other species. Z. Biol. Chem., 164: 702-723.

Firat, O., Cogun, H.Y., Yüzereroğlu, T.A., Gok, G., Firat, O., Kargin, F. and Kotemen, Y., 2011. A comparative study on the effects of a pesticide (cypermethrin) and two metals (copper, lead) to serum biochemistry of Nile tilapia Oreochromis niloticus. Fish Physiol. Biochem., 37: 657-666. https://doi.org/10.1007/ s10695-011-9466-3

Georgieva, E., Stoyanova, S., Velcheva, I. and Ancheva, V., 2014. Histopathological alterations in common carp (Cyprinus carpio L.) gills caused by Thiamethoxam. Braz. Arch. Biol. Tech., 57: 991996. https://doi.org/10.1590/S1516-8913201402582

Guner, U., 2009. Determination of lambda-cyhalotrin (Tekvando 5EC) 96 hour lethal concentration 50 at Gambusia affinis (Baird and Girard, 1853). $J$. Fish. Sci., 3: 214-219. https://doi.org/10.3153/ jfscom. 2009026

Hrubec, T., Smith, S., Robertson, J., Feldman, B., Veit, H., Libey, G. and Tinker, M., 1996. Comparison of hematologic reference intervals between culture 
system and type of hybrid striped bass. Am. J. Vet. Res., 57: 618-623.

Jain, N.C., 1986. Schalman's veterinary haematology, 4th edition. Lea and Babings, Philadelphia, P.A, U.S.A.

Jenkins, F., Smith, J., Rajanna, B., Shameem, U., Umadevi, K., Sandhya, V. and Madhavi, R., 2003. Effect of sub-lethal concentrations of endosulfan on hematological and serum biochemical parameters in the carp Cyprinus carpio. B Environ. Contam. Toxicol., 70: 0993-0997. https://doi.org/10.1007/ s00128-003-0080-7

Jensen, E.G., Skaare, J.U., Egaas, E. and Goksoyr, A., 1991. Response of xenobiotic metabolizing enzymes in rainbow trout (Oncorhynchus mykiss) to endosulfan, detected by enzyme activities and immunochemical methods. Aquat. Toxicol., 21: 1-2. https://doi.org/10.1016/0166-445X(91)90007-V

John, P. and Prakash, A., 2003. Bioaccumulation of pesticides on some organs of freshwater catfish Mystus vittatus. Bull. environ. Contam. Toxicol., 70: 1013-1016. https://doi.org/10.1007/s00128-0030083-4

Khan, B.A., Farid, A., Khan, N., Rasul, K. and Perveen, K., 2006. b Survey of pesticide use on fruits and vegetables in district Peshawar. Sarhad J. Agric., 22: 497.

Khan, N., Tabassam, S., Ahmad, M.S., Norouz, F., Ahmad, A., Ghayyur, S., Rehman, A.U. and Khan, M.F., 2018. Effects of sub lethal concentration of cypermethrin on histopathological and hematological profile of rohu (labeo rohita) during acute toxicity. Int. J. Agric. Biol., 20: 601-608. https://doi.org/10.17957/IJAB/15.0527

Kishor, H., Kalita, M. and Borkotoki, A., 2014. Acute toxicity of endosulphan on Channa punctatus (Bloch). Int. J. Res. Environ. Sci. Technol., 4: 88-92.

Lakshmaiah, G., 2017. Brain histopathology of the fish Cyprinus carpio exposed to lethal concentrations of an organophosphate insecticide phorate. Int. J. Adv. Res. Dev., 2: 668-672. https://doi.org/10.7439/ijasr. v2i4.3233

Lermen, C.L., Lappe, R., Crestani, M., Vieira, V.P., Gioda, C.R., Schetinger, M.R.C., Baldisserotto, B., Moraes, G. and Morsch, V.M., 2004. Effect of different temperature regimes on metabolic and blood parameters of silver catfish Rhamdia quelen. Aquaculture, 239: 497-507. https://doi. org/10.1016/j. aquaculture.2004.06.021

Masud, S. and Singh, I.J., 2013. Effect of cypermethrin on some hematological parameters and prediction of their recovery in a freshwater Teleost, Cyprinus carpio. Afri. J. environ. Sci. Technol., 7: 852-856.

Medina, M., Barata, C., Telfer, T. and Baird, D., 2002. Age-and sex-related variation in sensitivity to the pyrethroid cypermethrin in the marine copepod Acartia tonsa Dana. Arch. environ. Contam. Toxicol., 42: 17-22. https://doi.org/10.1007/s002440010286

Montanha, F.P., Fredianelli, A.C., Wagner, R., Sacco, S.R., Rocha, D.C.C. and Pimpao, C.T., 2014. Clinical, biochemical and haemathological effects in Rhamdia quelen exposed to cypermethrin. Arq. Bras. Med. Vet. Zootec., 66: 697-704. https://doi. org/10.1590/1678-41625934

Moraes, F.D., Venturini, F.P., Cortella, L.R.X., Rossi, P.A. and Moraes, G., 2013. Acute toxicity of pyrethroidbased insecticides in the Neotropical freshwater fish Brycon amazonicus. Ecotoxicol. environ. Contam., 8: 59-64. https://doi.org/10.5132/eec.2013.02.009

Nafees, M. and Jan, M., 2009. Residues of cypermethrin and endosulfan in soils of Swat valley. Soil Environ., 28: 113-118.

Neelima, P., Cyril, L., Arun, K.J., Rao, C.S. and Rao, N.G., 2015. Histopathological alterations in gill, liver and kidney of Cyprinus carpio (Linn.) exposed to Cypermethrin (25\%EC). Int. J. Adv. Res. biol. Sci., 2: 34-40.

Ojutiku, R.O., Asuwaju, F.P., Ayanda, O. and Obande, R.A., 2013. Effect of Acute Toxicity of Cypermethrin on Some biochemical Parameters of Juveniles of Claria Gariepinus. (Burchell, 1822). Int. J. Engineer. Sci. Invent., 3: $2319-6726$.

Orun, I., Talas, S.Z., Gulhan, M.F. and Erdogan, K., 2014. Role of propolis on biochemical and hematological parameters of Oncorhynchus mykiss exposed to cypermethrin. J. Surv. Fish. Sci., 1: 21-35. https:// doi.org/10.18331/SFS2014.1.1.3

Pimpao, C.T., Zampronio, A.R. and Silva-De-Assis, H.C., 2007. Effects of deltamethrin on hematological parameters and enzymatic activity in Ancistrus multispinis (Pisces, Teleostei). Pestic. Biochem. Physiol., 88: 122-127. https://doi.org/10.1016/j. pestbp.2006.10.002

Qureshi, I.Z., Bibi, A., Shahid, S. and Ghazanfar, M., 2016. Exposure to subacute doses of fipronil and buprofezin in combination or alone induces biochemical, hematological, histopathological and genotoxic damage in common carp (Cyprinus carpio L.). Aquat. Toxicol., 179: 103-114. https:// doi.org/10.1016/j.aquatox.2016.08.012

Ranzani-Paiva, M.J.T., Romagosa, E. and Ishikawa, C.M., 2005. Hematological parameters of "cachara", Pseudoplatystoma fasciatum Linnaeus, 1766 (Osteichthyes, pimelodidae), reared in captivity. 
Bol. Inst. Pesca., 31: 47-53.

Santos, T.G. and Martinez, C.B.R., 2012. Atrazine promotes biochemical changes and DNA damage in a neotropical fish species. Chemosphere, 89: $1118-1125$. https://doi.org/10.1016/j. chemosphere.2012.05.096

Seth, N. and Saxena, K.K., 2003. Hematological responses in a freshwater fish Channa punctatus due to fenvalerate. B Environ. Contam. Toxicol, 71: 1192-1199. https://doi.org/10.1007/s00128-0038732-1

Sharma, V., Anderson, D. and Dhawan, A., 2012. Zinc oxide nanoparticles induce oxidative DNA damage and ROS-triggered mitochondria mediated apoptosis in human liver cells (HepG2). Apoptosis, 17: 852-870. https://doi.org/10.1007/s10495-0120705-6

Singh, N.P., McCoy, M.T., Tice, R.R. and Schneider, E.L., 1988. A simple technique for the quantization of low levels of DNA damage in individual cells. Exp. Cell Res., 175: 184-191. https://doi.org/10.1016/00144827(88)90265-0

Soderlund, D.M., Clark, J.M., Sheets, L.P., Mullin, L.S., Piccirillo, V.J., Sargent, D., Stevens, J.T. and Weiner, M.L., 2002. Mechanisms of pyrethroid neurotoxicity: implications for cumulative risk assessment. Toxicology, 171: 201-205. https://doi. org/10.1016/S0300-483X(01)00569-8

Sreekala, G. and Zutshi, B., 2012. Alterations in the biochemical profile and metabolic enzyme in tissues of Labeo rohita. The Bioscan., 7: 359-364.

Srivastava, N. and Kaushik, N., 2001. Use of fish as bioindicator of aquatic pollution, Proceedings of the International Congress of Chemistry and Environment (ed. S.L. Gargh). pp. 227-229.

Thophon, S., Kruatrachue, M., Upatham, E.S., Pokethitiyook, P., Sahaphong, S. and Jaritkhuan, S., 2003. Histopathological alterations of white seabass, Lates calcarifer, in acute and subchronic cadmium exposure. Environ. Pollut., 121: 307-320. https:// doi.org/10.1016/S0269-7491(02)00270-1

Topal, A., Atamanalp, M., Oruc, E., Demir, Y., Beydemir, S. and Isik, A., 2014. In vivo changes in carbonic anhydrase activity and histopathology of gill and liver tissue after acute exposure to chlorpyrifos in rainbow trout. Arh. Hig Rada Toksikol., 65: 377-385. https://doi.org/10.2478/10004-1254-65-2014-2547

Ullah, R., Zuberi, A., Naeem, M. and Ullah, S., 2015. Toxicity to hematology and morphology of liver, brain and gills during acute exposure of Mahseer (Tor putitora) to cypermethrin. Int. J. Agric. Biol., 17: 199-204.

Van der Oost, R., Beyer, J. and Vermeulen, N.P., 2003. Fish bioaccumulation and biomarkers in environmental risk assessment: a review. Environ. Toxicol. Pharmacol., 13: 57-149. https://doi. org/10.1016/S1382-6689(02)00126-6

Velisek, J., Wlasow, T., Gomulka, P., Svobodova, Z., Dobsikova, R., Novotny, L. and Dudzik, M., 2006. Effects of cypermethrin on rainbow trout (Oncorhynchus mykiss). Vet. Med., 51: 469-476. https://doi.org/10.17221/5580-VETMED

Velmurugan, B., Cengiz, E.I., Senthilkumaar, P., Uysal, E. and Satar, A., 2016. Hematological parameters of freshwater fish Anabas testudineus after sublethal exposure to cypermethrin. Environ. Pollut. Protec., 1: 32-39. https://doi.org/10.22606/epp.2016.11004

Wang, X., Xue, F., Hua, A. and Ge, F., 2006. Effects of diapause duration on future reproduction in the cabbage beetle, Colaphellus bowringi: positive or negative? Physiol. Ent., 31: 190-196. https://doi. org/10.1111/j.1365-3032.2006.00508.x

World Health Organization., 2002. The WHO recommended classification of pesticides by hazard, guidelines to classification. (www.inchem.org/ documemts).

Zahran, E., Risha, E., Awadin, W. and Palic, D., 2018. Acute exposure to chlorpyrifos induces reversible changes in health parameters of Nile tilapia (Oreochromis niloticus). Aquat. Toxicol., 197: 4759. https://doi.org/10.1016/j.aquatox.2018.02.001

Zanjani, S.A., Emadi, H., Jamili, S. and Mashinchian, A., 2017. DNA damage and hematological changes in common carp (Cyprinus carpio) exposed to oxadiazon. Int. J. aquat. Biol., 5: 387-392. 